\title{
An Empirical Study of HRM Systems, Human and Social Capital Development and their Influence on Innovation Capabilities
}

\author{
Esin Akay $^{1 *}$,Ozlem Kunday ${ }^{2}$ \\ ${ }^{1}$ PhD Candidate, Faculty of Economics \& Admin. Sciences, Business Administration Department, Yeditepe \\ University, 26 August Campus, 34755 Atasehir, Istanbul, Turkey \\ ${ }^{2}$ Associate Prof., Faculty of Economics \& Admin. Sciences, Business Administration Department, Yeditepe \\ University, 26 August Campus, 34755 Atasehir, Istanbul, Turkey
}

*Corresponding Author: Esin Akay, PhD Candidate, Faculty of Economics \& Admin. Sciences, Business Administration Department, Yeditepe University, 26 August Campus, 34755 Atasehir, Istanbul, Turkey

\begin{abstract}
The aim of this study is to examine HRM systems, human and social capital development and their influence on innovation capabilities in production and service organizations in Turkey. Primary data is collected from two hundred and fifteen employees. The collected data is analyzed by using structural equation modelling. Human capital development mediates the relationship between high-profile personal HRM system and innovation capabilities. Also, the relationship between collective HRM system and innovation capabilities is influenced by the mediating effect of social capital development. Moreover, there is a direct and significant relationship between high-profile and collaborative HRM systems. The impact of social capital development on human capital development is significant and positive. When the moderating effect of sector is tested, sector moderates the above mentioned relationships, but it does not have any moderating effect on the relationship between the two HRM systems and the relationship between social and human capital development. Managers should carefully use these two HRM systems to develop human and social capital within their organizations, and they should be very skilful in managing the mediating effect of human and social capital so that the innovation capabilities of their organizations can be positively improved.
\end{abstract}

Keywords: HRM Systems; Innovation Capabilities; Human Capital Development; Social Capital Development; Production Sector; Service Sector.

\section{INTRODUCTION}

Today, growing global competition, volatile markets and higher customer expectations force the world of business to be in an everlasting state of change where continuous innovation is the one and only strategy for survival of individuals and organizations (Peters, 1997). As a result, innovation is essential. Suranyi-Unger (1994) has stated that organizational innovation is the introduction of any new product, process or system, and academicians such as Avermaete, Viaene, Morgan \& Crawford (2003) have written that product, process, organizational and market innovation are the four types of innovation. These four different kinds of innovation are needed for the survival and also for the successful sustainability of people and businesses.

Stone (2009) has defined Human Resource Management as the use of people for attaining strategic business objectives. According to Mondy (2010), some of the HRM practices implemented by organizations are staffing, training and compensation. Huselid(1995) and Boselie, Dietz \& Boon (2005)have stated that traditional human resource management research has taken a systematic approach to comprehend the bundle of high performance HRM practices in affecting business performance. To understand the relationship between HRM and organizational performance, Becker \& Huselid (2006) have suggested the introduction of different HRM systems which target different organizational capabilities. Instead of single and isolated types of HR practices, researchers like Guesta \& Conway (2011) have linked certain types of "bundles" or "systems" of HRM practices that have been named as high-performance work systems.

According to Laursen (2002), HR practices enhance each other, so HR practices are more effective in influencing innovation if they are applied in a form of integrated systems. As Gupta \& Singhal (1993) 
have stated, HRM is an originator of innovation, and effective HRM can make an organization become innovative, but small amount of research has been conducted to capture the effects of particular HRM systems in forecasting innovation, so too much is still unknown about how HRM systems will add to organizational innovation. Although Schuler \& MacMillan (1984), Van de Ven (1986), Schuler \& Jackson (1987) have agreed on the significance of human resources for innovation, the synergy between HRM practices and organizational innovation has received little attention until recently (Shane \& Ulrich, 2004). Moreover, the empirical research focusing on innovative HRM systems has just started (Laursen \& Foss, 2003; Shipton, West, Dawson, Birdi \& Patterson, 2006; Jimenez-Jimenez \&Sanz-Valle, 2008).

Academics such as Wright, McMahan \& McWilliams, (1994) and Becker \& Gerhart, (1996) have stated that human resources play an important role in increasing organization's competitive advantage since employees' knowledge and skills can be the sources of competitive advantage, and Van de Ven (1986) has stressed that the grounds of innovation are ideas, and it is people who generate and develop ideas. The simple supposition in the relationship between them is that the innovation capacity of an organization is inherent in its employees' competences and motivation. Stated differently, innovation is the serious enabler for organizational value creation and sustainable competitive advantage, and it is driven by organization's capacity to manage its intellectual capital (Chen \& Huang, 2009). Subramaniam \& Youndt (2005) also have emphasized that the innovation capability of an organization is thoroughly interrelated to its intellectual capital.

Swart \& Kinnie (2010) have stated that managers ought to develop HRM initiatives which aim to generate and refine intellectual capital composed of human, social and organizational capital, because they help an organization to improve its innovation capacity. As Youndt, Subramaniam \& Snell (2004) have indicated, intellectual capital refers to the summation of all types of knowledge which organizations exploit for competitive advantage. The significance of intellectual capital for innovation has attracted researchers' interest in defining its components and the process by which it augments the innovation capabilities of organizations. Human capital is defined as intellectual capital in the form of individual knowledge and skills of employees. Social capital is the collective knowledge which is rooted in the social relationships amongst employees.

Research has emphasized the role of HRM as a tool for managing human and social capital, and Youndt, Subramaniam \& Snell (2004) have demonstrated that HRM investment has a noteworthy role in creating human and social capital. Subramaniam \& Youndt (2005) have concluded that an organization's efforts in hiring, training and implementing other HRM practices need to focus not only on maintaining their employees' skills and expertise, but also on developing their abilities to collaborate and share information and knowledge. Consequently, Donate, Pena \& Sanches de Pablo (2016) have researched high-profile HR practices and collaborative HR practices that are crucial for human and social capital development.

Despite the fact that many organizations in Turkey apply modern HRM practices, they do not result in innovation since HRM practices are not combined in a holistic system so that they can lead to the increase of innovation capabilities through the influence of human and social capital development. Besides, there is lack of empirical research on the relationships among HRM systems, human and social capital development and innovation. Taking all of these into consideration, investigating the influences of HRM systems on innovation capabilities through the mediating effects of human and social capital development in production and service organizations in Turkey is the objective of this study.

\section{THEORETICAL BACKGROUND AND HYPOTHESES}

\subsection{High-profile HRM System, Human Capital Development, Innovation Capabilities}

When academic literature is reviewed, it is found that some earlier studies have examined innovation as dependent variable, and some HRM academics have noticed that effective HRM practice has a positive influence on organizational innovation. Scholars such as De Leede \& Looise (2005), Shipton, West, Dawson, Birdi \& Patterson, (2006) and Beugelsdijk (2008) have also found that human resource management practices play a significant role at enhancing organizational innovation. Shipton et al., (2006) have conducted a longitudinal study of 22 manufacturing companies in Britain, and they have found that effective HRM systems like training, induction, team working and evaluation can predict products and production technology innovation. Donate, Pena \& Sanches de Pablo (2016) 
have studied the innovation impact of high-profile HRM practices such as selective staffing, training, performance appraisal and compensation.

Innovative capacity of an organization is inherent in the intelligence, imagination and creativity of its employees (Kanter, 1989; Gupta \& Singhal, 1993; Mumford, 2000) and their contributions are needed for the implementation of innovation (Van de Ven, 1986; Vrakking, 1990). Becker (1964) has mentioned that employees' human capital is the knowledge and skills of individual employees attained from education and experience. Similarly defined by other scholars like Roos, Dragonetti \& Edvinson (1997) and Bontis (1998), the human capital consists of the competencies, experience and commitment of employees. Studies have shown that employees bring different demographic backgrounds (Cox, 1993), personalities (Hough \& Schneider, 1996), past experiences (Rousseau, 2001), attitudes (Brief, 1998) and motivations (Locke \& Latham, 1990), all of which influence their ways of understanding and reacting to organizational experiences.

According to Smith, Collins \& Clark (2005), innovation is "a function of organization's ability to create, manage and maintain knowledge", and because knowledge is created by individuals and it is kept within individuals (Grant, 1996), scholars have assumed that HR practices affecting the behavior of human resources might be fundamental in the innovation process. HRM may enable the investigation of problems and promote employees to discover existing knowledge, which consequently stimulates organizational innovation (Shipton, West, Dawson, Birdi \& Patterson, 2006). Lately, researchers have begun to study the role of HRM for creativity and innovation (JimenezJimenez \& Sanz-Valle 2008; Lin 2011). In particular, organizations can hire new employees who have creative capability, offer training programs and re-design reward systems to strengthen the creative behaviors of employees.

Chatman (1991) has emphasized that recruitment targets should match the knowledge and attitudes of candidates to the requirements of the job. Staffing is a main HRM practice for innovation and when it is implemented, the organization is more likely to hire employees who are capable of learning the unique knowledge that is essential for the organization's competitiveness, and in this manner constructing human capital that will be valuable for the organization (Subramaniam \& Youndt, 2005; Sekiguchi, 2007). The cautious recruitment and selection of talented people may play a crucial role in crafting the circumstances required for innovation, so successful organizations create recruiting networks to systematically search for new talent and to build a pool of creative employees. A broad selection and hiring procedure by using more recruiting sources, rigorous interviews, screening tests will increase the amount of information collected about each applicant before making a hiring decision (Raghuram \& Arvey, 1994).

Training is the deliberate effort intended by an organization in supporting its employees in the learning process of job related competencies which are critical for the success of employees' job performances (Noe et al., 2008). Concerning training, some studies have underlined the significance of the broad application of training in order to develop employee skills and knowledge desired for innovation (Laursen \& Foss, 2003; Mak \& Akhtar, 2003). Appropriate opportunities for training support and encourage employees to find new ideas and to advance them further (Shalley \& Gilson, 2004; Jiang, Wang \& Zhao, 2012). Based on a survey of 332 organizations in Hong Kong, Lau \& Ngo (2004) have demonstrated that some HRM practices and particularly training is related to organizations' innovation performance.

Another HRM function is performance appraisal which is also important for innovation. Harackiewicz \& Elliot (1993) and Egan (2005) have connected performance appraisal to increased levels of employee motivation and creativity. When feedback and mistake toleration are an integral part of performance appraisal, it may facilitate the development of creativity. Feedback provided during the appraisal process leads to a recognition of the gaps between performance and targets (Shipton et al. 2006), so this motivates employees to work creatively. Moreover, tolerating the mistakes of employee when they try new ideas and approaches is very critical for innovation. Consequently, toleration of mistakes should be included in the performance appraisal of employees.

As Folger \& Konovsky (1989) have specified compensation is what organizations pay employees in exchange for their labor. Compensation is essential part in the high-profile HR system, so innovative organizations should design compensation packages to attract the best skilled employees (Turbin \& Rosse, 1990). Rewards can attract creative people and retain them (Starkey, Tempest \& Mckinlay, 
2004), and they can offer motivation for the additional effort necessary for innovation (Shipton et al., 2006). Organizations should offer incentives (Galbraith, 1984; Miles \& Snow, 1984) to encourage employees to develop creative activities (Cascio, 1990; Gupta \& Singhal, 1993). Some researchers such as Van Reenen (1996) and Balkin et al. (2000) have found a positive link between innovation and employee salaries level. Given the theoretical and empirical evidence in the academic literature, the first hypotheses can be proposed as:

H1: The correlation between high-profile personal HRM system and innovation capabilities is influenced through the mediating effect of human capital development.

\subsection{Collaborative HRM System, Social Capital Development, Innovation Capabilities}

Nahapiet \& Ghoshal (1998) have theorized social capital as the summation of the actual and potential resources embedded within, available through and resulting from the networks of relationships possessed by an individual or social unit. According to Spender (1996) "collective knowledge" is tacit and it is situated in a social dimension, so it is the most challenging aspect of intellectual capital to manage and measure. This also explains why collective knowledge is the most strategic type of knowledge. Grounded in the work of Granovetter (1992), some scholars have underlined the significance of social capital for innovation. Tsai \& Ghoshal (1998) have demonstrated that this social aspect affects resource exchange and the coordination among the people involved, which also creates value for the organization through its effect on product innovation.

Social capital is the knowledge that is rooted in organization's relations with its employees, customers, suppliers and others in the external environment. Since there are relationships with internal and external parties, there are internal and external kinds of social capital (De Pablos, 2004). For the internal social capital, forming teams and teamwork are crucial. The "bonding view" highlights internal social capital, and it stems from the network closure theories (Coleman, 1988). It stresses building a cohesive work environment with teams in which employees share knowledge and resources that are critical for innovation. According to Katzenbach \& Smith (1993), a team is made of a small group of people who possess different skills that complement one another. Consequently, teamwork occurs since the group members collaborate to realize the team's goal.

There is a great amount of research on teams in relation to innovation, which is studied by analyzing features of teams, members and environment and how this affects teams (Hülsheger, Anderson \& Salgado, 2009), yet there are fewer studies that have examined the use of teamwork in organizations, and how it influences innovation (Naveh \& Erez, 2004). Many academics such as Hackman (1990) and Guzzo et al. (1992) have claimed that the organizational context within which teams operate will impact their performance. HRM creates the "context" which can enable or weaken the influence of teamwork for innovation. The HRM practices that have a group orientation are labelled as collaborative (Lepak \& Snell, 1999). Lopez-Cabrales, Perez-Luno \& Cabrera (2009) have defined collaborative HR systems as the management of internal human capital to develop teamwork and cross-functional teamwork skills.

In this study, work autonomy, broad job design, empowerment, teamwork and group-oriented incentives are the "collaborative HRM system" as Donate, Pena \& Sanches de Pablo (2016) also have examined. Collaborative HRM practices have team orientation like selection of individuals according to their team competencies, training activities explaining how to work in teams, and team-based appraisals and compensation practices. In the collaborative system, skills for teamwork are necessary to pass any selection procedure. The collaborative HR model includes training individuals in developing their interpersonal skills. This type of training has a positive effect on innovation because it facilitates employee interaction with colleagues and encourages the flow of new ideas and perspectives within work teams (Ulrich, 1998; Lepak et al., 2003).

Another main feature of self-directed teams is the autonomy they have over work operations (Morgeson et al., 2006). According to Amabile (1996) and Urbach, Fay \& Goral (2010), autonomy results in a sense of responsibility, and it increases intrinsic motivation, which in turn is associated with formation and implementation of new ideas. When employees work on complex jobs that have high levels of autonomy, feedback, identity and variety (Hackman \& Oldham, 1980), they are likely to experience high levels of intrinsic motivation and respond to this motivation by developing creative ideas. Employee involvement, teamwork and flexible job assignment programs motivate employees as 
well as ensure employee discretion and opportunities to innovate (Ichniowski, Shaw\& Prennushi, 1997; Batt, 2002).

Regarding job design, literature claims that organizations should allow employees to have free time for developing new ideas and design jobs for working with ambiguity and tolerance (Schuler \& Jackson, 1987). The design of jobs is a central provider to employee creativity through increasing the intrinsic motivation to be creative (Shalley \& Gilson, 2004). As a result, jobs should promote job enrichment (Tushman \& Nadler, 1986; Kydd \& Oppenheim, 1990), flexibility in job definition (Tushman \& Nadler, 1986), autonomy (Kanter 1985; Axtell, Holman, Unsworth, Wall \& Waterson, 2000), employee participation (Cummings, 1965; Schuler \& Jackson 1987) and fluent communication (Cummings, 1965; Albertini \& Butler, 1995). When jobs are broadly defined and self-direction is allowed, employees are able to find new solutions to problems in the workplace (Lepak \& Snell, 1999; Kang et al., 2007).

Team process variables are more strongly related to creativity and innovation measured at team than individual level. In a better managed team, members can be motivated to perform at higher levels of creativity by social comparison processes providing group members and teams with a comparison standard and providing feedback on individual or team performance (West, 2002). Team cooperation, communication and conflict resolution are critical dimensions in teams with innovation expectation (Beer \& Eisenstat, 2000). Therefore, a teamwork design is critical for distributing specialized knowledge throughout the organization. When there is a high level of interaction among team members, the cross-fertilization of standpoints can produce creativity and innovation is more likely to occur.

Research has stressed the role of communication and information gathering for organizational innovation (Monge, Cozzens \& Contractor, 1992). Similarly, Nahapiet \& Ghoshal (1998) argued that the relational dimension of social capital may represent increased willingness to experiment with combining different types of information as well as to develop new knowledge. Implementing HRM practices like the delegation of responsibilities and the involvement of employees in decision making improve organization's social capital, thus strengthening the flow and exchange of information within teams (Ulrich, 1998). Evidence shows that empowerment and employee participation in decision making enable formal and informal work relations that provide employees with a network that they can use for sharing information (Adner \& Helfat, 2003).

Appraisal and compensation processes act in harmony with group criteria (Helleloid \& Simonin, 1994; Lepak \& Snell, 1999) and HR remuneration practices also contribute to enhancing social capital through the use of team-based incentives. West \& Markiewicz (2004) have identified that teamwork is inclined to fail if the reward system does not contain rewards for collaboration and achievement of team goals. Barczak \& Wilemon (2003) have underlined that team members possess strong interest in being remunerated according to the results generated by their teams. Laursen (2002) and Laursen \& Foss (2003) have empirically confirmed the positive impact of team-based pay on team performance as a motivating tool for sharing knowledge. Group-based incentives may enhance cooperative behavior and increase interaction among individuals because they recognize that part of their compensation depends on group results (Ulrich \& Lake, 1990; Snell \& Dean, 1994; Lepak \& Snell, 2002). Therefore, the next hypothesis is:

H2: Social capital mediates the relationship between collaborative HRM system and innovation capabilities.

\subsection{High-profile and Collaborative HRM Systems}

Academics like Gibbons (1998), Ichniowski \& Shaw (2003), and Bloom, Sadun \& Van Reenen (2010), have taken into consideration new HRM practices like employee training, teamwork, job design and internal hierarchies, all of which aim at enhancing employee performance. These personal high-profile HR practices integrated in a system are useful for managing individual employees. On the other hand, collaborative HRM practices are implemented for enriching social relationships that are grounds of innovation. Work environment that values teamwork is more likely to cultivate a sense of "public good" or collectivity (Ibarra, Kilduff \& Tsai, 2005), which invites individuals to trust the organization, share knowledge and innovate without private concerns (Moran, 2005). Among HRMinnovation studies there is an emphasis on social relationships in contributing to innovation (Kogut \& Zander, 1996; Collins \& Smith, 2006). 
The cross-functional team work and information sharing may develop internal knowledge and communication that serve as a common cognitive basis for effective communication and knowledge sharing (Nahapiet \& Ghoshal, 1998; Gittell et al., 2010). Practices such as teamwork and job rotation create structural connectedness among employees. These enable the exploitation of more fine grained, complex knowledge to facilitate innovation (Reagans, Zuckerman \& McEvily, 2004). Building from these observations, this study proposes the third hypothesis as:

\section{H3: There is a significant correlation between high-profile and collaborative HRM systems.}

\subsection{Human and Social Capital Development}

As it has been mentioned before, the main components of intellectual capital are human and social capital, and they have been already defined. The development of high quality human capital is important for forming and developing high quality social capital. Burt (1997) has emphasized that the value of human capital is meaningless without social capital. It means that social capital is essential for human capital. However, the "human capital advantage" described by Box all (1996), tends to decline over time. Stated differently, knowledge, skills and expertise tend to become outdated, so managers could boost high-quality relationships or social capital to arise spontaneously and could direct them towards organizational strategic objectives.

As it has been claimed by Snell, Youndt \& Wright (1996), organizations can prevent human capital from becoming outdated, and they can stimulate social capital by implementing particular HRM practices. By implementing appropriate HR practices, human and social capital can be directed to achieving organizational capabilities by spreading collective knowledge that can also enrich the individual knowledge of employees. Therefore, knowledge is updated, improved and disseminated within organizations (Lepak \& Snell, 1999; Currie \& Kerrin, 2003). Enriching social capital can be very beneficial for sustaining the value and uniqueness of human capital. According to Subramaniam \& Youndt (2005), innovative capabilities of organizations benefit less if individual knowledge is not networked, shared and channeled through relationships. Based on these, the next hypothesis is:

H4: Social capital development has a positive effect on human capital development.

\subsection{Sector and its Moderating Effect}

Since professionals who have participated in this study work for two different sectors, it would be beneficial to test the moderating effect of sector on the relationship between the constructs. Thus, the last hypothesis for this study is:

H5: Sector plays a moderating role in the correlations between the constructs.

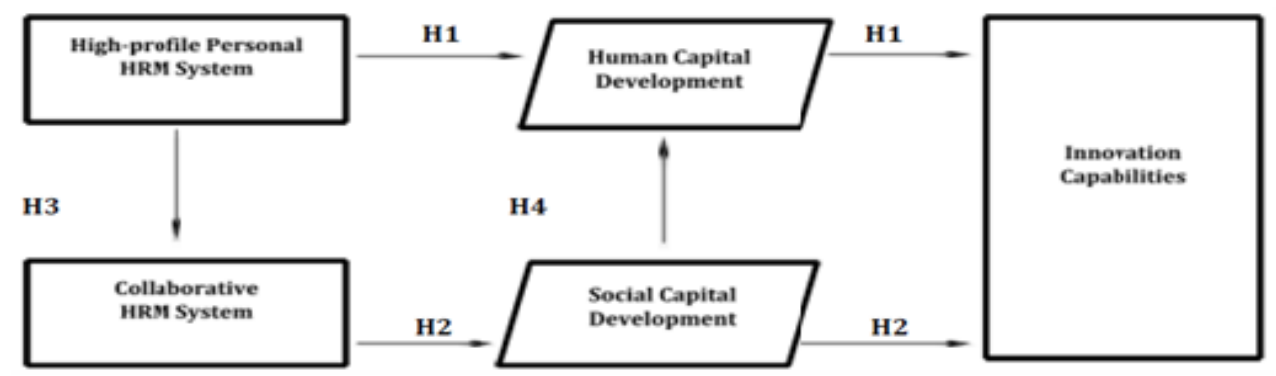

Figure1. Proposed Research Model

\section{MethodologY}

The research design of the present study is explanatory. In other words, it is correlation hypotheses testing research. Besides, it is cross-sectional and quantitative survey research that studies individuals as a unit of analysis. Also, the extent of the researcher's interference is minimal, and the study setting is non-contrived. Lastly, survey questionnaire is used to gather primary data for empirical analysis.

\subsection{Sample}

In this study, as a sampling technique convenience sampling that is a non-probability sampling technique is applied. Subjects' approachability and closeness to the researchers are the most important features of convenience sampling. As a result, the sample for this research has been chosen from service and production organizations in Istanbul since innovation is important for all types of organizations. The sample size is $n=230$ professionals who work for organizations located in Istanbul. They have been randomly selected by using LinkedIn and Facebook. 


\subsection{Procedure}

First of all, the survey questionnaire written in English has been translated to Turkish. Next, the Turkish version of the questionnaire has been prepared by using Survey Monkey website. The confidentiality of participation and data management have been carefully explained at the very beginning of the on-line survey questionnaire. Then, the link of the on-line survey questionnaire has been sent in three forms. Firstly, it has been sent as a direct e-mail message to 100 professionals. Then, it has been sent as LinkedIn message to 400, and finally as Facebook message to 400 professionals. The time period for unswerving the questionnaire and collecting the data had lasted for one month, more specifically from November 3, 2016 to December 3, 2016.

\subsection{Data Collection}

From the sent 900questionnaires, only 239 have been completed. 24 questionnaires have been omitted because of some unanswered items, so 215 questionnaires have been used as primary data for empirical analysis. The demographic data of the participants can be summarized as follow. In terms of gender, $54.4 \%$ of participants are men and $45.6 \%$ are women. $28.8 \%$ are $20-35$ years old, $63.7 \%$ are 36 - 50 years old, and $7.4 \%$ are 51 - 70 years old. In terms of education, only $0.9 \%$ hold a high school diploma. $43.3 \%$ hold a university degree, and $51.6 \%$ hold a master's degree, and $4.2 \%$ of participants hold $\mathrm{PhD}$. Finally, when the length of working life of participants is taken into account, $1.4 \%$ have been working for 1 to 3 years, $10.2 \%$ for 4 to $7,29.3 \%$ for 8 to 15 , and $59.1 \%$ have been working for 16 and more years. Finally, $28.8 \%$ of participants work for organizations in the production sector, whereas $71.2 \%$ work for service organizations.

\subsection{Measurement Instruments}

Items from validated measurement instruments used before have been chosen and adapted to guarantee the validity of survey instruments. Ranging from 1 to 5 , Likert-style multi-item scale has been used for each item.

High-profile personal HRM System: This measurement instrument includes seven items that have been adapted from Snell and Dean's (1992) measure. For this research, item 6 and item 2 have been deleted since their outer loadings have been lower than 0.70 . This instrument has reliability measure Cronbach $\alpha=0.864$.

Collaborative HRM System: The collaborative HRM system measure includes eight items taken from Youndt and Snell's (2004) research. In this study, items3,4,5,6 and 8 have been deleted because their outer loadings have been lower than 0.70 . Cronbach $\alpha$ is 0.754 .

Human Capital: Human capital development construct has been measured by using Youndt et al. (2004), and Subramaniam and Youndt (2005). This instrument has reliability measure Cronbach $\alpha$ is 0.916 .

Social Capital: To measure organization's social capital development, the well-known Youndt et al. (2004) 5 item scale has been implemented. Item 4 has been deleted because its outer loading has been lower than 0.70 . Cronbach $\alpha$ is 0.835 .

Innovation Capabilities: This four items scale has been adapted from Zahra \&Das (1993), and Zahra \& Bogner (2000). These four items have measured processes and product innovation in the organization in the last 3 years. Cronbach $\alpha$ is 0.897 .

Table1. Measurement Instruments

\begin{tabular}{|l|l|l|l|}
\hline \multicolumn{1}{|c|}{ Constructs } & Items & Cronbach $\boldsymbol{\alpha}$ & \multicolumn{1}{c|}{ Source } \\
\hline High-profile Personal HRM System (HPHRS) & 5 & 0.864 & Adapted from Snell \& Dean (1992) \\
\hline Collaborative HRMSystem (CHRS) & 3 & 0.754 & Adapted from Youndt \& Snell (2004) \\
\hline Human Capital (HC) & 4 & 0.835 & $\begin{array}{l}\text { Adapted from Youndt et al. (2004); } \\
\text { Subramaniam \& Youndt (2005) }\end{array}$ \\
\hline Social Capital (SC) & 4 & 0.835 & $\begin{array}{l}\text { Adapted from Youndt et al. (2004); } \\
\text { Subramaniam \& Youndt (2005) }\end{array}$ \\
\hline Innovation Capabilities (InnCap) & 4 & 0.897 & $\begin{array}{l}\text { Adapted from Zahra \& Das (1993); } \\
\text { Zahra \& Bogner (2000) }\end{array}$ \\
\hline
\end{tabular}

Table 1 illustrates Cronbach's Alpha results of all instruments. Values range from 0.754 to 0.916 . Statistically, for Cronbach's Alpha range above 0.70 is acceptable and over 0.80 is good. As a result, all the instruments have indicated high reliability. 
An Empirical Study of HRM Systems, Human and Social Capital Development and their Influence on Innovation Capabilities

\subsection{Data Analysis}

To analyze the proposed research model, the partial least squares (PLS) approach has been applied. According to Chin (1998), the PLS approach is a structural equation modeling (SEM).This technique simultaneously assesses a measurement model and the path constructed structural model at the same time. SEM is an appropriate technique for solving multi collinearity problems which often arise in multivariate regression analysis because it changes predictor variables to an orthogonal component (Chin et al., 2003).SmartPLS 3.0 software program has been used to conduct the analysis. Although measurement and structural parameters are assessed at the same time, a PLS model is usually applied in two stages. Firstly, the measurement model evaluates the reliability and validity of the theoretical constructs. Secondly, the structural model scrutinizes the path correlations postulated in the proposed model of this study.

\section{RESUlts}

\subsection{Measurement Model}

The measurement model in this study has been validated by assessing convergent and discriminant validity. As suggested by Fornell \& Larcker (1981) and Hair, Anderson, Tatham \& Black (1998), the convergent validity of the measurement instruments has been verified by using three criteria. Firstly, the loadings of all indicators have to be higher than 0.70 , secondly composite reliability (CR) figures have to be higher than 0.80 , and finally, the average variance extracted (AVE) for each construct has to be higher than 0.50 .

Table2. Measurement Model (Descriptive statistics, convergent \& discriminant validity results)

\begin{tabular}{|l|c|c|c|c|c|c|c|c|c|c|}
\hline \multicolumn{1}{|c|}{ Constructs } & Loadings & Mean & STDEV & CR & AVE & HPHRS & CHRS & HC & SC & InnCap \\
\hline HPHRS & $0.716-0.854$ & 0.650 & 0.025 & 0.903 & 0.651 & $\mathbf{0 . 8 0 7}$ & & & & \\
\hline CHRS & $0.783-0.871$ & 0.670 & 0.028 & 0.859 & 0.671 & 0.764 & $\mathbf{0 . 8 1 9}$ & & & \\
\hline HC & $0.808-0.912$ & 0.750 & 0.024 & 0.937 & 0.750 & 0.575 & 0.523 & $\mathbf{0 . 8 6 6}$ & & \\
\hline SC & $0.780-0.847$ & 0.668 & 0.030 & 0.890 & 0.668 & 0.551 & 0.632 & 0.622 & $\mathbf{0 . 8 1 8}$ & \\
\hline InnCap & $0.752-0.930$ & 0.768 & 0.022 & 0.929 & 0.768 & 0.551 & 0.537 & 0.563 & 0.540 & $\mathbf{0 . 8 7 6}$ \\
\hline
\end{tabular}

Loadings should be above 0.70. Correlations are significant at 0.001. The diagonal in bold demonstrates the square root of variance shared between the constructs and their measures (AVE).

Table2 shows the descriptive statistics, convergent and discriminant validity results of the measurement model. Indicator loadings are above 0.70 . The $C R$ values range from 0.859 to 0.937 , and AVE values range from 0.651 to 0.768 . Therefore, the above stated three convergent validity criteria have been satisfied. Besides, Table 2 displays the figures of construct relationships. For assessing discriminant validity, Fornell \& Larcker (1981) have suggested the criteria which are the square root of the AVE of a latent variable should be higher than the correlations between the rest of latent variables and the construct itself. Also, Table 2 illustrates the main diagonal showing the square root of the AVE of each construct, so the discriminant validity is supported in the measured model since this condition is satisfied for all constructs.

\subsection{Structural Model}

The cross-validation (CV) communality and redundancy results have been used to evaluate the quality of the structural model. Then, the proposed hypotheses have been verified. The overall quality of the structural model has been assessed by measuring the mean of the CV-communality results. According to Tenenhaus, Vinzi, Chatelin \& Lauro (2005), the model is of high quality when CV-communality results are positive for all the blocks, bearing in mind the measurement model. Tenenhaus et al., (2005) has concluded that the quality of each structural equation is usually estimated through the CV redundancy results, which should be positive for all the endogenous constructs, bearing in mind the measurement model.

Table3. Structural Model Quality

\begin{tabular}{|l|l|l|}
\hline \multicolumn{1}{|c|}{ Constructs } & \multicolumn{1}{c|}{ CV-communality } & CV-redundancy \\
\hline High-profile HR system (HPHRS) & 0.459 & 0.285 \\
\hline Collaborative HR system (CHRS) & 0.340 & 0.271 \\
\hline Human Capital (HC) & 0.587 & 0.322 \\
\hline Social Capital (SC) & 0.428 & 0.244 \\
\hline Innovation Capabilities (InnCap) & 0.572 & 0.303 \\
\hline
\end{tabular}

$Q^{2}>0$

International Journal of Managerial Studies and Research (IJMSR) 
An Empirical Study of HRM Systems, Human and Social Capital Development and their Influence on Innovation Capabilities

Table 3 displays the quality of the structural model. All the latent variables offer positive values for CV communality and redundancy results, so the model of this study demonstrates predictive validity and fit adequacy. Ringle et al. (2005) has stated that Stone-Geisser test, which uses $\mathrm{Q}^{2}$ results to estimate predictive relevance of dependent constructs is another method to evaluate the relevance of the calculated model. According to Chin (1998), this test represents how well observed results are reconstructed by the model and its parameter estimates. Since all these results $\left(\mathrm{Q}^{2}\right)$ are above 0 for the model, it meets the criteria. Consequently, the model has prediction relevance. After investigating the structural model quality, the correlations have been verified. As Chin (1998) has suggested, a bootstrap resampling procedure considering 500 sub-samples has been implemented to evaluate if the correlations and effects are significant.

Table4. Structural Model: Correlations

\begin{tabular}{|l|l|l|l|l|}
\hline Correlations & Mean & STDEV & T Statistics & P Values \\
\hline HPHRS $\rightarrow$ HC & 0.331 & 0.060 & 5.589 & 0.000 \\
\hline HC $\rightarrow$ InnCap & 0.270 & 0.079 & 3.408 & 0.001 \\
\hline CHRS $\rightarrow$ SC & 0.633 & 0.045 & 13.918 & 0.000 \\
\hline SC $\rightarrow$ InnCap & 0.183 & 0.075 & 2.415 & 0.016 \\
\hline HPHRS $\rightarrow$ CHRMS & 0.763 & 0.029 & 26.571 & 0.000 \\
\hline SC $\rightarrow$ HC & 0.441 & 0.067 & 6.560 & 0.000 \\
\hline
\end{tabular}

$p<0.05$

In Table 4 the path correlations of the structural model are depicted. Taking into account the $\mathrm{p}$ values as $\mathrm{p}<0.05$, it can be stated that all correlations are significant.

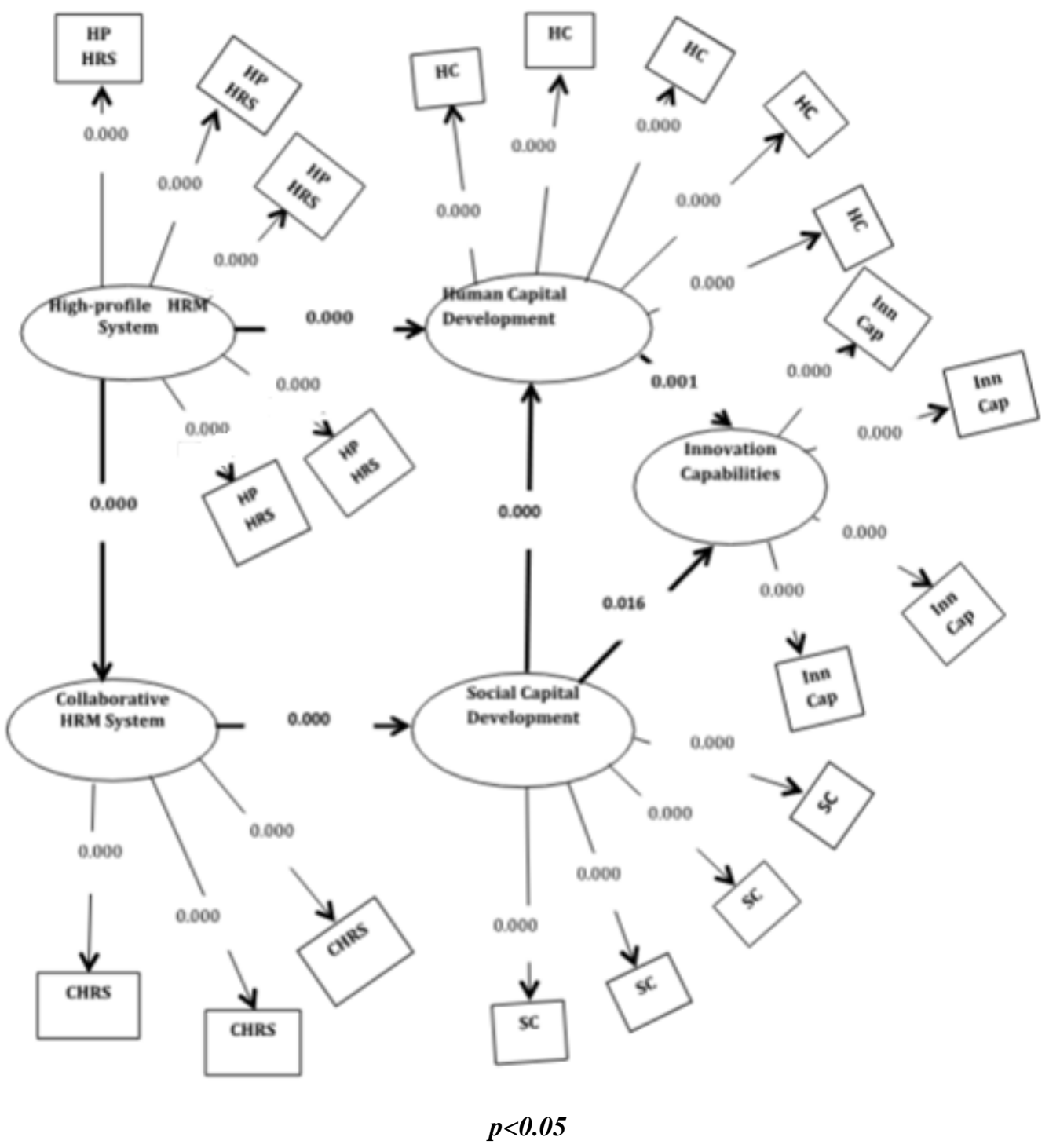

Figure2. SEM Results (Bootstrapping Graphic) 
Figure 2 illustrates the bootstrapping graphic summary results of the structural equation model where the significance of indicator loadings and path coefficients are shown. As illustrated, the results from the factor analysis for all factor loadings and their path correlations are significant, $(\mathrm{p}<0.05)$. When the path correlations between all constructs are considered the results are as follow. The relationship between high-profile HRM system and human capital development is significant (path coefficient $=0.000, \mathrm{p}<0.05$ ), and the relationship between human capital development and innovation capabilities is also significant (path coefficient $=0.001, \mathrm{p}<0.05$ ). Consequently, the human capital development mediates the correlation between high-profile HRM system and innovation capabilities, thus $\mathrm{H} 1$ is supported. The correlation between collaborative HRM system and social capital development (path coefficient $=0.000, \mathrm{p}<0.05$ ) is significant. Besides, the relationship between social capital development and innovation capabilities is also significant (path coefficient $=0.016, p<0.05$ ), so $\mathrm{H} 2$ is supported, and this means that social capital development has a mediating effect on the relationship between collaborative HRM system and innovation capabilities. Since the relationship between high profile HRM system and collaborative HRM system is significant (path coefficient $=0.000, \mathrm{p}<0.05), \mathrm{H} 3$ is supported. Stated differently, high profile HRM system has a direct and positive impact on collaborative HRM system. H4 is also supported because the correlation between social capital development and human capital development is significant (path coefficient $=0.000, \mathrm{p}<0.05$ ). In other words, the development of social capital has a direct and positive effect on the development of human capital.

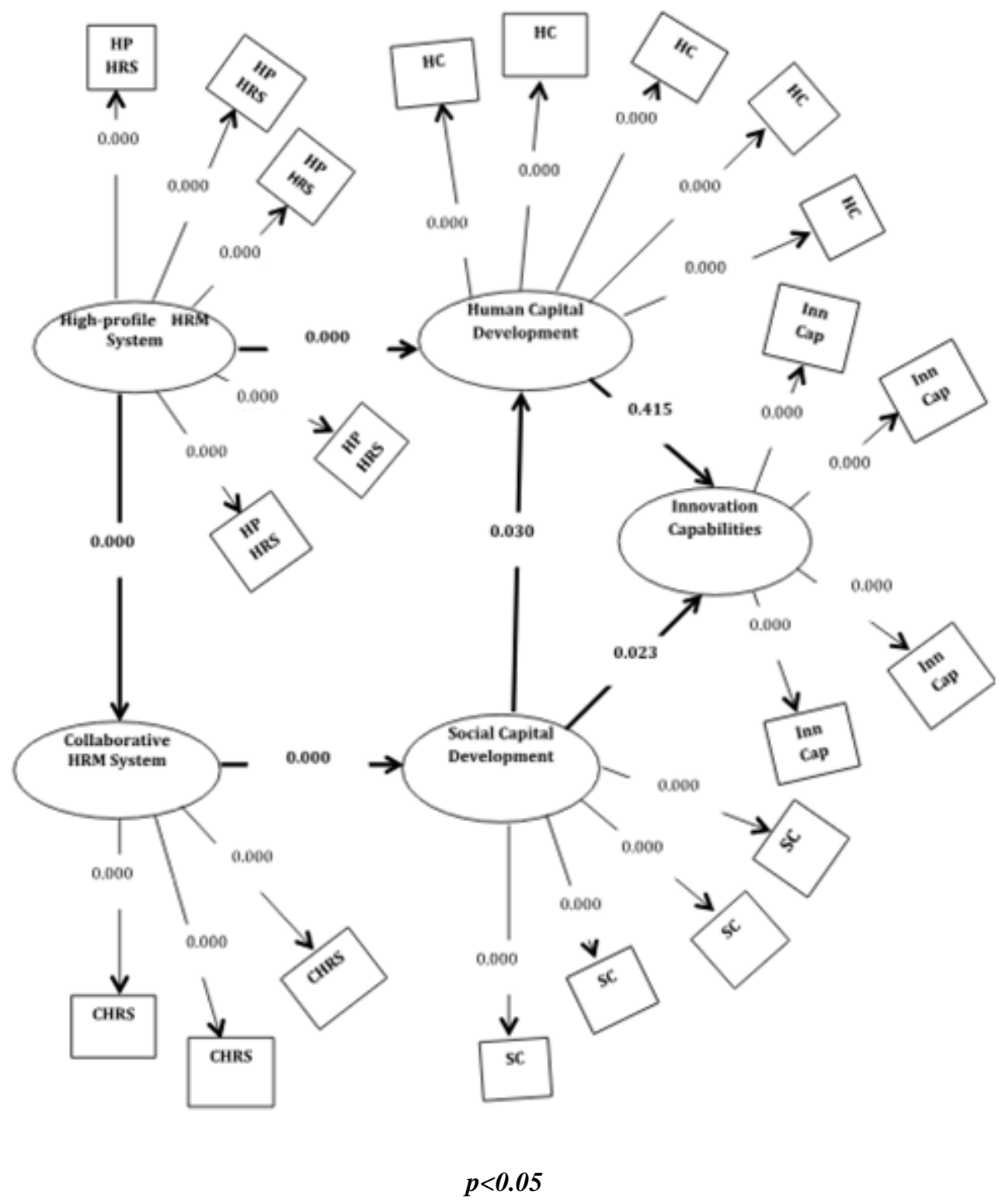

Figure3. SEM Results (Production Sector) 


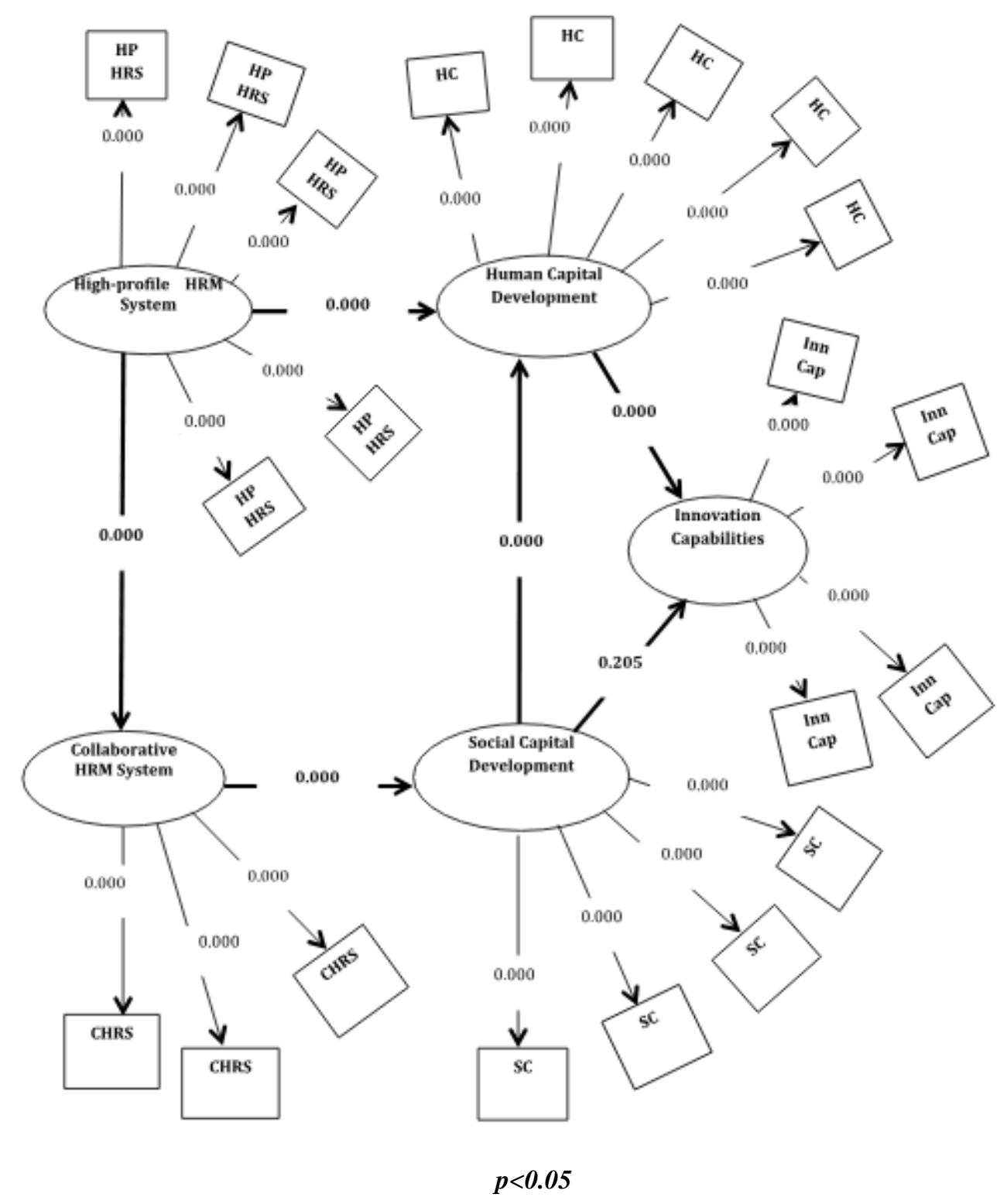

Figure4. SEM Result (Service Sector)

Two more bootstrapping graphics have been generated to test if there are any similarities and differences in the structural models when the moderating effect of sector is considered. The production sector has been tested by using data provided by 62 participants, and service sector has been examined by using data provided by 153 participants. When Figure 3 and Figure 4 are analyzed, it can be observed that there are some similarities and differences in the path model estimations between the two sectors.

H1 is not supported for the production sector because the mediating effect of human capital development is not observed since the relationship between high-profile HRM system and human capital development is significant (path coefficient $=0.000, \mathrm{p}<0.05$ ), yet the second relationship between human capital development and innovation capabilities is insignificant (path coefficient $=0.415, \mathrm{p}<0.05$ ). On the other hand, $\mathrm{H} 1$ is fully supported for the service sector because human capital development plays a mediating role in the relationship between high- profile HRM system and human capital development (path coefficient $=0.000, \mathrm{p}<0.05$ ), and human capital development and innovation capabilities (path coefficient $=0.000, \mathrm{p}<0.05$ ).In terms of $\mathrm{H} 1$ the two sectors are different. It can be concluded that sector moderates the relationship defined in H1.

$\mathrm{H} 2$ is supported for the production sector because the mediating effect of social capital development is observed since the relationship between collaborative HRM system and social capital development is significant (path coefficient $=0.000, \mathrm{p}<0.05$ ). Moreover, the relationship between social capital 
development and innovation capabilities is significant (path coefficient $=0.023, \mathrm{p}<0.05$ ). Contrary, $\mathrm{H} 2$ is not supported for the service sector since social capital development does not play a mediating role in the relationship between collaborative HRM system and social capital development (path coefficient $=0.000, \mathrm{p}<0.05$ ), and social capital development and innovation capabilities (path coefficient $=0.205, \mathrm{p}<0.05$ ). As a result the two sectors are different when $\mathrm{H} 2$ is analyzed, so sector moderates the relationship stated in $\mathrm{H} 2$.

The relationship between high-profile HRM system and collaborative HRM system is significant (path coefficient $=0.000, \mathrm{p}<0.05$ ) for the both sectors, and $\mathrm{H} 3$ is supported. There is not any moderation effect of sector in the relationship discussed in H3. Lastly, sector does not moderate the correlation defined in $\mathrm{H} 4$ because the correlation between social capital development and human capital development is significant (path coefficient $=0.030, \mathrm{p}<0.05$ ) for the production sector and it is also significant (path coefficient $=0.000, \mathrm{p}<0.05$ ) for the service sector.

\section{DISCUSSION}

The first main contribution of the present study is the empirical examination of the proposed research model in production and service organizations in Turkey. The study also investigates the role of HRM systems, and the mediating effects of human capital development and social capital development in facilitating innovation capabilities. Besides, it tests if sector plays a moderating effect in the relationships between the constructs. Another main contribution is that the first and the second hypotheses are supported, so human capital development mediates the relationship between highprofile HRM system and innovation capabilities, and social capital development mediates the relationship between collaborative HRM system and innovation capabilities.

When the correlation between high-profile HRM and collaborative HRM systems is examined in hypothesis three, it is found that there is a positive and significant correlation between these two systems. Consequently, it can be concluded that the implementation of high-profile HRM system positively affects the collaborative HRM system, so organizations and managers should be aware of this. Sector does not play any moderating effect here. Finally, it is observed that social capital development has a positive effect on human capital development as stated in H4. Thus, the hypothesis is supported for the production sector. Similarly, it is supported for organizations in the service sector. In other words, the development of social capital in organizations is beneficial for the development of human capital, and sector does not have any moderating effect on this relationship.

\subsection{Implications}

As it is stated in the literature, human capital development and social capital development are critical strategic factors for enhancing organizational innovation capabilities. In other words, it should be emphasized that all managers and specifically HR managers should not ignore human capital development and social capital development. This study offers some advice to help all managers but especially HR managers to understand how to integrate some HR practices into high-profile personal and collaborative HRM systems, and how to implement these for developing human and social capital so that they can influence innovation capabilities. As a result, the findings of this research have several managerial implications.

The research reveals the importance of combining HRM practices for enhancing human capital. It recommends that organizations have to promote high-profile personal HRM system, and HR and all other managers should engage in supporting human capital development since it affects innovation. Moreover, HRM practices in a collaborative HRM system should be implemented for enriching social capital that can also lead to innovation. HRM systems play a fundamental role in aiding employees, teams and organizations to apply their individual and collective knowledge and creativity so as to form the core organizational competences required for product, service and process innovations. This research also shows that the critical factors for innovation are actually intangible, so all managers including HR managers should be aware and skillful in managing intangible variables such as human and social capital.

Finally, the research findings reflect that HRM systems indirectly influence innovation capability through the mediating effects of human and social capital development. Thus, human and social capital developments play a mediating role to link HRM systems and innovation capabilities. As a result, it should be underlined that if managers overlook the human and social capital development, they cannot directly boost innovation. In order to increase innovation, managers have to use the HRM 
systems and apply them for developing human and social capital. To sum up, the present study helps managers to better understand how to implement HRM systems so as to increase innovation through the mediating effect of human and social capital development.

\subsection{Limitations and Recommendations}

Limitations should be considered when interpreting the findings of this study. The first limitation is that cross-sectional data have been used, and this has not permitted causal inferences about the longitudinal interplay between the variables. The second limitation is the short time period for collecting the data. It is recommended that further research should be longitudinal in which the variables could be measured at different time periods to provide some additional insights. It is also recommended that future research gathers some measures of independent and dependent variables from different data sources to minimize the effects of any response bias. More research in this field can study the relationships between variables in different cultural and organizational setting. Only two HRM systems have been studied, so it is recommended that future research examines the impact of other HRM systems on human and social capital development and their influence on innovation capabilities.

\section{CONCLUSION}

In today's volatile environment, organizations depend on their innovative capabilities to increase their competitive advantage. Innovation is driven by human and social capital, and these reside in the individual competencies and motivations of employees and in the social relations build among employees and teams. Hence, human and social capitals have to be effectively accumulated, shared and applied so that organizations can benefit from them in order to innovate. The issue addressed in this article is on how two HRM systems can be used for human and social capital development and innovation. The study of HRM becomes critically relevant because it is specifically concerned with people management. It is proposed that HRM systems can be integrated to encourage and manage the processes of knowledge acquisition, sharing and application in order to enhance the intellectual capital within an organization.

The proposed research model captures how the mediating effects of human capital development and social capital development influence innovation capabilities. This article contributes to the body of research on developing HRM systems for the formation of innovative organizations that are capable to encounter the challenges of continuous change. By using data collected from production and service organizations in Turkey, and by analyzing the data with the help of structural equation modeling, this study investigates some HRM practices which influence innovation capabilities through the mediating effects of human and social capital development.

The study findings indicate that HRM practices integrated in high-profile personal and collaborative HRM systems are important determinants of human and social capital development and innovation. Generally, the findings demonstrate that HRM systems do not impact innovation capabilities directly but indirectly. It has been proposed that human capital development mediates the correlation between high-profile HRM system and innovation capabilities. Besides, social capital development plays a mediating role in the relationship between collaborative HRM system and social capital development. The main findings support these hypotheses. As a result, it should be concluded that human capital development and social capital development do play mediating roles. In addition, the moderating effect of sector has been investigated in this study, and it has been found that some relationships are influenced by it. Managers, have to be very careful since sector can play a moderating effect.

\section{REFERENCES}

[1] Peters, T. (1997), The Circle of Innovation, Hodder \&Stoughton, London.

[2] Suranyi-Unger, T. (1994). Innovation. In D. Greenwald (Ed.), Encyclopedia of Economics. New York: McGraw-Hill.

[3] Avermaete, T., Viaene, J., Morgan, E.J., \&Crawford, N. (2003), Determinants of Innovation in Small Food Firms, European Journal of Innovation Management, 6, 8-17.

[4] Stone, R.J. (2009). Managing Human Resources: An Asian Perspective, 1st ed., John Wiley \& Sons, Milton.

[5] Mondy, R.W. (2010). Human Resource Management, 11th ed., Pearson/Prentice Hall, Upper Saddle River, NJ.

[6] Huselid, M. A. (1995). The Impact of Human Resource Management Practices on Turnover, Productivity, and Corporate Financial Performance. Academy of Management Journal, 38, 635-72. 
[7] Boselie, P., Dietz, G., \& Boon, C. (2005). Commonalities and Contradictions in HRM and Performance Research. Human Resource Management Journal, 15, 3, 67-92.

[8] Becker, B. E., \& Huselid, M. A. (2006). Strategic human resources management: Where do we go from here? Journal of Management, 32, 898-925.

[9] Guesta, D., \& Conway, N. (2011), The Impact of HR Practices, HR Effectiveness and a "Strong HR System" on Organizational Outcomes: A Stakeholder Perspective, International Journal of Human Resource Management, 22, 1686-1702.

[10] Laursen, K., (2002), The Importance of Sectoral Differences in the Application of Complementary HRM Practices for Innovation Performance,International Journal of Economics and Business, 9, 139-156.

[11] Gupta, A., \& Singhal, A. (1993). Managing Human Resources for Innovation and Creativity. Research Technology Management, 36, 3, 41-48.

[12] Schuler, R. S., \& MacMillan, I. C. (1984). Gaining Competitive Advantage through Human Resource Management Practices. Human Resource Management, 23, 241-255.

[13] Van de Ven, A. H. (1986). Central Problems in the Management of Innovation. Management Science, 32, 590-607.

[14] Schuler, R. S., \& Jackson, S. E. (1987). Linking Competitive Strategies with Human Resource Management Practices. Academy of Management Executive, 1, 207-219.

[15] Shane, S. A., \& Ulrich, K. T. (2004). Technological Innovation, Product Development, and Entrepreneurship in Management Science. Management Science, 50, 133-144.

[16] Laursen, K., \& Foss, N. J. (2003). New Human Resource Management Practices, Complementarities and the Impact on Innovation Performance. Cambridge Journal of Economics, 27, 243-263.

[17] Shipton, H., West, M.A., Dawson, J.F., Birdi, K. \&Patterson, M. (2006) HRM as a Predictor of Innovation. Human Resource Management Journal, 16, 3-27.

[18] Jimenez-Jimenez D. \& Sanz-Valle R. (2008). Could HRM Support Organizational Innovation? The International Journal of Human Resource Management, 19, 7, 1208-1221.

[19] Wright, P. M., McMahan, G. C., \& McWilliams, A. (1994). Human Resources and Sustained Competitive Advantage: A Resource-Based Perspective. International Journal of Human Resource Management, 5, 301-326.

[20] Becker, B., \& Gerhart, B. (1996). The Impact of Human Resource Management on Organizational Performance: Progress and Prospects. Academy of Management Journal, 39, 779-801.

[21] Van de Ven, A. H. (1986). Central Problems in the Management of Innovation. Management Science, 32 , 590-607.

[22] Chen, C. J., \&Huang, J. W. (2009). Strategic Human Resource Practices and Innovation Performance The Mediating Role of Knowledge Management Capacity. Journal of Business Research, 62, 104-114.

[23] Subramaniam, M., \& Youndt, A. (2005). The Influence of Intellectual Capital on the Types of Innovative Capabilities. Academy of Management Journal, 48, 450-463.

[24] Swart, J., \& Kinnie, N. (2010). Organisational Learning, Knowledge Assets and HR Practices in Professional Service Firms. Human Resource Management Journal, 20, 64-79.

[25] Youndt, M. A., Subramaniam, M., \& Snell, S. A. (2004). Intellectual Capital Profiles: An Examination of Investments and Returns. Journal of Management Studies, 41, 335-361.

[26] Youndt, M. A., Subramaniam, M., \& Snell, S. A. (2004). Intellectual Capital Profiles: An Examination of Investments and Returns. Journal of Management Studies, 41, 335-361.

[27] Subramaniam, M., \& Youndt, M. A. (2005). The Influence of Intellectual Capital on the Types of Innovative Capabilities. Academy of Management Journal, 48, 450-463.

[28] Donate, M. J., Peña I. \& Sánchez de Pablo J. D. (2016). HRM Practices for Human and Social Capital Development: Effects on Innovation Capabilities, The International Journal of Human Resource Management, 27, 9, 928-953.

[29] De Leede, J., \& Looise, J. C. (2005). Innovation and HRM: Towards an Integrated Framework. Creativity and Innovation Management, 14, 2, 108-117.

[30] Shipton, H., West, M.A., Dawson, J.F., Birdi, K. \&Patterson, M. (2006) HRM as a Predictor of Innovation. Human Resource Management Journal, 16, 3-27.

[31] Beugelsdijk, S. (2008). Strategic Human Resource Practices and Product Innovation. Organization Studies, 29, 821-847.

[32] Shipton, H., West, M.A., Dawson, J.F., Birdi, K. \&Patterson, M. (2006) HRM as a Predictor of Innovation. Human Resource Management Journal, 16, 3-27. 
[33] Donate, M. J., Peña I. \& Sánchez de Pablo J. D. (2016). HRM Practices for Human and Social Capital Development: Effects on Innovation Capabilities, The International Journal of Human Resource Management, 27, 9, 928-953.

[34] Kanter, R. (1989), Swimming in Newstreams: Mastering Innovation Dilemmas, Journal of Business Venturing, 45-68.

[35] Gupta, A., \& Singhal, A. (1993). Managing Human Resources for Innovation and Creativity. Research Technology Management, 36, 3, 41-48.

[36] Mumford, M. D. (2000). Managing Creative People: Strategies and Tactics for Innovation. Human Resource Management Review, 10, 3, 313-351.

[37] Van de Ven, A. H. (1986). Central Problems in the Management of Innovation. Management Science, 32, 590-607.

[38] Vrakking, W.J. (1990), The Innovative Organization,Long Range Planning, 23, 2, 94-102.

[39] Becker, G.S. (1964), Human Capital: A Theoretical Analysis with Special Reference to Education, New York: Columbia University Press.

[40] Roos, J., Roos, G., Dragonetti, N.C. and Edvinson, L. (1997). Intellectual Capital: Navigating in the New Business Landscape. Basingtoke: Macmillan.

[41] Bontis, N. (1998). Intellectual Capital: An Exploratory Study that Develops Measures and Models. Management Decision, 36, 2, 63-76.

[42] Cox, T. (1993). Cultural Diversity in Organizations: Theory, Research and Practice. San Francisco, CA: Berret-Koehler.

[43] Hough, L. M., \& Schneider, R. J. (1996). Personality Traits, Taxonomies and Applications in Organizations. In M. Kevin (Ed.), Individual differences and behavior in organizations,31-88. San Francisco, CA: Jossey-Bass.

[44] Rousseau, D. M. (2001). Schema, Promise and Mutuality: The Building Blocks of the Psychological Contract. Journal of Occupational and Organizational Psychology, 74, 4, 511-541.

[45] Brief, A. P. (1998). Attitudes in and around Organizations. Thousand Oaks, CA: Sage.

[46] Locke, E., \& Latham, G. (1990). A Theory of Goal Setting and Task Performance. Englewood Cliffs, NJ: Prentice Hall.

[47] Smith, K.G., Collins, C.J., and Clark, K.D. (2005), Existing Knowledge, Knowledge Creation Capability and the Rate of New Product Introduction in High-technology Firms, Academy of Management Journal, 48, 346-357.

[48] Grant, R.M. (1996), Toward a Knowledge-based Theory of the Firm,Strategic Management Journal, 17, 109-122.

[49] Shipton, H., West, M.A., Dawson, J.F., Birdi, K. \&Patterson, M. (2006) HRM as a Predictor of Innovation. Human Resource Management Journal, 16, 3-27.

[50] Jimenez-Jimenez D. \& Sanz-Valle R. (2008). Could HRM Support Organizational Innovation? The International Journal of Human Resource Management, 19, 7, 1208-1221.

[51] Lin, L.H. (2011), Electronic Human Resource Management and Organizational Innovation: the Roles of Information Technology and Virtual Organizational Structure, The International Journal of Human Resource Management, 22, 235-257.

[52] Chatman, J.A. (1991). Matching people and organization: selection and socialization in public accounting firms.Administrative Science Quarterly, 36, 3, 459-84.

[53] Subramaniam, M., \& Youndt, A. (2005). The Influence of Intellectual Capital on the Types of Innovative Capabilities. Academy of Management Journal, 48, 450-463.

[54] Sekiguchi, T. (2007), A Contingency Perspective of the Importance of PJ Fit and PO Fit in Employee Selection,Journal of Managerial Psychology, 22, 2, 118-131.

[55] Raghuram, S., \& Arvey, R.D. (1994), Business Strategy Links with Staffing and Training Practices,Human Resource Planning, 17, 3, 55-73.

[56] Noe, R.A., J. R. Hollenbeck, B. Gerhart, \& Wright, P.M. (2008), Human Resource Management - Gaining a Competitive Advantage, 6th ed., McGraw-Hill, New York, NY.

[57] Laursen, K., \& Foss, N. J. (2003). New Human Resource Management Practices, Complementarities and the Impact on Innovation Performance. Cambridge Journal of Economics, 27, 243-263.

[58] Mak, S., \& Akhar, S. (2003). HRM practices, strategy orientations and company performance: A correlation study of publicly listed companies. Journal of American Academy of Business, 2(2), 510-515.

[59] Shalley, C. E., \& Gilson, L. L. (2004). What Leaders Need to Know: A Review of Social and Contextual Factors that can Foster or Hinder Creativity. Leadership Quarterly, 15, 1, 33-53. 
[60] Jiang, J., Wang, S. and Zhao, S. (2012) Does HRM Facilitate Employee Creativity and Organizational Innovation? A Study of Chinese Firms. International Journal of Human Resource Management, 23, 4025-47.

[61] Lau, C.-M. and Ngo, H.-Y. (2004) The HR System, Organizational Culture, and Product Innovation. International Business Review, 13, 685-703.

[62] Harackiewicz, J.M., and Elliot, A.J. (1993), Achievement Goals and Intrinsic Motivation,Journal of Personality and Social Psychology, 65, 904-915.

[63] Egan, T.M. (2005), Factors Influencing Individual Creativity in the Workplace: An Examination of Quantitative Empirical Research, Advances in Developing Human Resources, 7, 160-181.

[64] Shipton, H., West, M.A., Dawson, J.F., Birdi, K. \&Patterson, M. (2006) HRM as a Predictor of Innovation. Human Resource Management Journal, 16, 3-27.

[65] Folger, R., \& Konovsky, M. A. (1989). Effects of Procedural and Distributive Justice on Reactions to Pay Raise Decisions. Academy of Management Journal, 32, 1, 115-130.

[66] Turbin, M.S., and Rosse, J.G. (1990), Staffing Issues in the High Technology Industry,Organizational Issues in High Technology Management, eds. L.R. Gómez Mejı'a and M.W. Lawless, Greenwich, CT: JAI Press, $227-242$.

[67] Starkey, K., Tempest, S., and Mckinlay, A. (2004), How Organizations Learn: Managing the Search for Knowledge, London: Thomson.

[68] Shipton, H., West, M.A., Dawson, J.F., Birdi, K. \&Patterson, M. (2006) HRM as a Predictor of Innovation. Human Resource Management Journal, 16, 3-27.

[69] Galbraith, J.R. (1984), Human Resource Policies for the Innovating Organization,in Strategic Human Resource Management, eds. C. Fobrun, N.M. Tichy and M.A. Devanna, USA: John Wiley \& Sons, 319-341.

[70] Miles, R.E., and Snow, C.C. (1978), Organizational Strategy, Structure and Process, New York: McGraw Hill.

[71] Cascio, W.F. (1990), Strategic Human Resource Management in High Technology Industry, in Organizational Issues in High Technology Management, eds. L.R. Gómez Mej1'a and M.W. Lawless, Greenwich, CT: JAI Press Inc, 179-197.

[72] Gupta, A., \& Singhal, A. (1993). Managing Human Resources for Innovation and Creativity. Research Technology Management, 36, 3, 41-48.

[73] Van Reenen, J. (1996), The Creation and Capture of Rents: Wages and Innovation in a Panel of UK Companies, The Quarterly Journal of Economics, 111, 1, 195-226.

[74] Balkin, D., Markman, G., \& Gomez-Mejia, L. (2000). Is CEO pay in high technology firms related to innovation? Academy of Management Journal, 43, 6, 1118-1129.

[75] Nahapiet, J., \& Ghoshal, S. (1998). Social Capital, Intellectual Capital and the Organizational Advantage. Academy of Management Review, 23, 242-266.

[76] Spender, J.C. (1996). Making Knowledge the Basis of a Dynamic Theory of the Firm. Strategic Management Journal, 17, 45-62.

[77] Granovetter, M. (1992), Problems of Explanations in Economic Sociology,in Networks and

[78] Organizations: Structure from Action, eds. N. Nohria and R. Eccles, Boston, MA: Harvard Business School Press, 25-56.

[79] Tsai, W., \& Ghoshal, S. (1998). Social capital and value creation: The role of intrafirm networks. Academy of Management Journal, 41, 464-476.

[80] De Pablos, P.O. (2004). Human Resource Management Systems and Their Role in the Development of Strategic Resources: Empirical Evidence. Journal of European Industrial Training, 28, 6, 174-189.

[81] Coleman, J. S. (1988). Social Capital in the Creation of Human Capital. The American Journal of Sociology, 94, 95-120.

[82] Katzenbach, J.R. \& D. K. Smith, (1993). The Discipline of Teams. Harvard Business Review, 71, 2, 111-20

[83] Hülsheger, U.R., Anderson, N. \& Salgado, J.F. (2009) Team-Level Predictors of Innovation at Work: A Comprehensive Meta-Analysis Spanning Three Decades of Research. Journal of Applied Psychology, 94, 1128-45.

[84] Naveh, E. \& Erez, M. (2004) Innovation and Attention to Detail in the Quality Improvement Paradigm. Management Science, 50, 1576-86.

[85] Hackman, J.R. (1990) Groups that Work (and those that don't). Jossey Bass, San Francisco, CA.

[86] Guzzo, R.A., Shea, G.P., Dunnette, M.D. and Hough, L.M. (1992) Group Performance and Intergroup Relations in Organizations. In Dunnette, M.D. and Hough, L.M. (Eds.), Handbook of Industrial and Organizational Psychology, 3, 2nd ed. Consulting Psychologists Press, Palo Alto, CA, 269-313.

[87] Lepak, D. P., \& Snell, S. A. (1999). The Human Resource Architecture: Toward a Theory of Human Capital Allocation and Development. Academy of Management Review, 24, 1, 31-48. 
[88] Lopez-Cabrales A., Perez-Luno A. \& Cabrera R.V. (2009). Knowledge as a Mediator between HRM Practices and Innovative Activity, Human Resource Management, 48, 4, 485- 503.

[89] Donate, M. J., Peña I. \& Sánchez de Pablo J. D. (2016). HRM Practices for Human and Social Capital Development: Effects on Innovation Capabilities, The International Journal of Human Resource Management, 27, 9, 928-953.

[90] Ulrich, D. (1998). Intellectual Capital $=$ Competence $\times$ Commitment. Sloan Management Review, 39, 2, 15-26.

[91] Lepak, D. P., Takeuchi, R., \& Snell, S. A. (2003). Employment Flexibility and Firm Performance: Examining the Interaction Effects of Employment Mode, Environmental Dynamism and Technological Intensity. Journal of Management, 29, 5, 681-703.

[92] Morgeson, F.P., Johnson, M. D., Campion, M. A., Medsker, G.J. and Mumford, T. V. (2006) Understanding Reactions to Job Redesign: A Quasi- Experimental Investigation of the Moderating Effects of Organizational Context on Perceptions of Performance Behaviour. Personnel Psychology,59, 333-63.

[93] Amabile, T.M. (1996) Creativity in Context.Westview Press, Boulder, CO.

[94] Urbach, T., Fay, D. and Goral, A. (2010) Extending the Job Design Perspective on Individual Innovation: Exploring the Effect of Group Reflexivity. Journal of Occupational and Organizational Psychology, 83, 1053-64.

[95] Hackman, J.R. \& Oldham, G.R. (1980) Work Redesign. Addison-Wesley, Reading, Mass.

[96] Ichniowski, C., ShawK.\& Prennushi G. (1997). The Effects of Human Resource Management Practices on Productivity: A Study of Steel Finishing Lines.American Economic Review,87, 3, 291-313.

[97] Batt, R. (2002). Managing Customer Services: Human Resource Practices, Quit Rates and Sales Growth. Academy of Management Journal, 45, 587-597.

[98] Schuler, R. S., \& Jackson, S. E. (1987). Linking Competitive Strategies with Human Resource Management Practices. Academy of Management Executive, 1, 207-219.

[99] Shalley, C. E., \& Gilson, L. L. (2004). What Leaders Need to Know: A Review of Social and Contextual Factors that can Foster or Hinder Creativity. Leadership Quarterly, 15, 1, 33-53.

[100] Tushman, M.L., \& Nadler, D.A. (1986), Organizing for Innovation, California Management Review, 28, 3, 74-92.

[101] Kydd, C.T., \& Oppenheim, L. (1990), Using Human Resource Management to Enhance Competitiveness: Lessons from Four Excellent Companies, Human Resource Management, 29, 2, 145-166.

[102] Tushman, M. L., \& Nadler, D.A. (1986), Organizing for Innovation, California Management Review, 28, 3, 74-92.

[103] Kanter, R. (1985), Supporting Innovation and Venture Development in Established Companies, Journal of Business Venturing, 1, 47-60.

[104] Axtell, C.M., Holman, D.J., Unsworth, K.L., Wall, T. D., \& Waterson, P.E. (2000), Shopfloor Innovation: Facilitating the Suggestion and Implementation of Ideas, Journal of Occupational \& Organizational Psychology, 73, 3, 265-285.

[105] Cummings, L. (1965), Organizational Climates for Creativity, Academy of Management Journal, 3, $220-227$.

[106] Schuler, R. S., \& Jackson, S. E. (1987). Linking Competitive Strategies with Human Resource Management Practices. Academy of Management Executive, 1, 207-219.

[107] Cummings, L. (1965), Organizational Climates for Creativity, Academy of Management Journal, 3, 220227.

[108] Albertini, S., \&Butler, J. (1995), R\&D Networking in a Pharmaceutical Company: Some Implications for Human Resource Management, R\&D Management, 25, 4, 377-393.

[109] Lepak, D. P., \& Snell, S. A. (1999). The Human Resource Architecture: Toward a Theory of Human Capital Allocation and Development. Academy of Management Review, 24, 1, 31-48.

[110] Kang, S. C., Morris, S. S., \& Snell, S. A. (2007). Relational Archetypes, Organizational Learning and Value Creation: Extending the Human Resource Architecture. Academy of Management Review, 32, 236-256.

[111] West, M. A. (2002). Ideas are Ten a Penny: It's Team Implementation not Idea Generation that Counts. Applied Psychology, 51, 3, 411-424.

[112] Beer, M., \& Eisenstat, R.A. (2000), TheSilent Killers of Strategy Implementation and Learning,Sloan Management Review, 41, 29-40.

[113] Monge, P.R., Cozzens, M. D., \&Contractor, N.S. (1992), Communication and Motivational Predictors of the Dynamics of Organizational Innovation, Organization Science, 3, 250-274. 
[114] Nahapiet, J., \& Ghoshal, S. (1998). Social Capital, Intellectual Capital and the Organizational Advantage. Academy of Management Review, 23, 242-266.

[115] Ulrich, D. (1998). Intellectual Capital $=$ Competence $\times$ Commitment. Sloan Management Review, 39, 2, $15-26$.

[116] Adner, R., \& Helfat, C. (2003), Corporate Effects and Dynamic Managerial Capabilities,Strategic Management Journal, 24, 1011-1025.

[117] Helleloid, D., \& Simonin, B. (1994). Organizational Learning and a Firm's Core Competence. In G. Hamel \& A. Heene (Eds.), Competence-based competition. New York: Wiley.

[118] Lepak, D. P., \& Snell, S. A. (1999). The Human Resource Architecture: Toward a Theory of Human Capital Allocation and Development. Academy of Management Review, 24, 1, 31-48.

[119] West, M. A. \& Markiewicz, L. (2004) Building Team-Based Working: A Practical Guide to Organizational Transformation. Blackwell Publishing, Malden, MA.

[120] Barczak, G., \& Wilemon, D. (2003). Team Members’ Experiences in New Product Development, Views from the Trenches. R \& D Management, 33, 5, 463-479.

[121] Laursen, K., (2002), The Importance of Sectoral Differences in the Application of Complementary HRM Practices for Innovation Performance,International Journal of Economics and Business, 9, 139-156.

[122] Laursen, K., \& Foss, N. J. (2003). New human resource management practices, complementarities and the impact on innovation performance. Cambridge Journal of Economics, 27, 243-263.

[123] Ulrich, D., \& Lake, D. (1990), Organizational Capability: Competing from the Inside Out, New York: Wiley.

[124] Snell, S., \&Dean, J. W. (1992). Integrated Manufacturing and Human Resource Management: A Human Capital Perspective. Academy of Management Journal, 35, 467-504.

[125] Lepak, D. P., \& Snell, S. A. (2002). Examining the Human Resource Architecture: The Relationships among Human Capital, Employment and Human Resource Configurations. Journal of Management, 28, 517-543.

[126] Gibbons, R. (1998). Incentives in Organizations. Journal of Economic Perspectives 12, 4, 115-132.

[127] Ichniowski, C., \&Shaw, K. (2003). Beyond Incentive Pay: Insiders' Estimates of the Value of Complementary Human Resource Management Practices. Journal of Economic Perspectives, 17, 1, 155-180.

[128] Bloom, N., SadunR., \&Van ReenenJ.,(2012). Americans Do IT Better: US Multinationals and the Productivity Miracle.American Economic Review,102, 1, 167-201.

[129] Ibarra, H., Kilduff, M., \& Tsai, W. (2005). Zooming in and out: Connecting Individuals and Collectivities at the Frontiers of Organizational Network Research. Organization Science, 16, 359-371.

[130] Moran, P. (2005). Structural vs. Relational Embeddedness: Social Capital and Managerial Performance. Strategic Management Journal, 26, 1129-1151.

[131] Kogut, B., \& Zander, U. (1996). What Do Firms Do? Coordination, Identity and Learning. OrganizationScience, 7, 502-518.

[132] Collins, C. J., \& Smith, K. G. (2006). Knowledge exchange and combination: The role of human resource practices in the performance of high-technology firms. Academy of Management Journal, 49, 3, 544-560.

[133] Nahapiet, J., \& Ghoshal, S. (1998). Social Capital, Intellectual Capital and the Organizational Advantage. Academy of Management Review, 23, 242-266.

[134] Gittell, J. H., Seidner, R., \& Wimbush, J. (2010). A Relational Model of How High-Performance Work Systems Work. Organization Science, 21, 490-506.

[135] Reagans, R., Zuckerman, E., \& McEvily, B. (2004). How to Make the Team: Social Networks vs. Demography as Criteria for Designing Effective Teams. Administrative Science Quarterly, 49, 101-133.

[136] Burt, R. S. (1997). The Contingent Value of Social Capital. Administrative Science Quarterly, 42, 339-365.

[137] Boxall, P. (1996), The Strategic HRM Debate and the Resource-based View of the Firm, Human Resource Management Journal, 6, 59-75.

[138] Snell, S., Youndt, M., \& Wright, P. (1996), Establishing a Framework for Researching in Strategic Human Resource Management: Merging Resource Theory and Organizational Learning, Research in Personnel and Human Resource Management, 14, 61-90.

[139] Lepak, D. P., \& Snell, S. A. (1999). The Human Resource Architecture: Toward a Theory of Human Capital Allocation and Development. Academy of Management Review, 24, 31-48.

[140] Currie, G.,\& Kerrin M. (2003). Human Resource Management and Knowledge Management: Enhancing Knowledge Sharing in a Pharmaceutical Company.The International Journal of Human Resource Management, 14, 6, 1027-45. 
An Empirical Study of HRM Systems, Human and Social Capital Development and their Influence on Innovation Capabilities

[141] Subramaniam, M., \& Youndt, M. A. (2005). The Influence of Intellectual capital on the Types of Innovative Capabilities. Academy of Management Journal, 48, 450-463.

[142] Snell, S., \&Dean, J. W. (1992). Integrated Manufacturing and Human Resource Management: A human Capital Perspective. Academy of Management Journal, 35, 467-504.

[143] Youndt, M. A., \& Snell, S. A. (2004). Human Resource Configurations, Intellectual Capital, and Organizational Performance. Journal of Managerial Issues, 14, 337-360.

[144] Youndt, M. A., Subramaniam, M., \& Snell, S. A. (2004). Intellectual Capital Profiles: An Examination of Investments and Returns. Journal of Management Studies, 41, 335-361.

[145] Subramaniam, M., \& Youndt, M. A. (2005). The Influence of Intellectual Capital on the Types of Innovative Capabilities. Academy of Management Journal, 48, 450-463.

[146] Youndt, M. A., Subramaniam, M., \& Snell, S. A. (2004). Intellectual Capital Profiles: An Examination of Investments and Returns. Journal of Management Studies, 41, 335-361.

[147] Zahra, S. A., \& Das, S. R. (1993). Innovation Strategy and Financial Performance in Manufacturing Companies: An empirical study. Production and Operations Management, 2, 15-37.

[148] Zahra, S. A., \& Bogner, W. C. (2000). Technology Strategy and Software New Ventures' Performance. Journal of Business Venturing, 15, 135-173.

[149] Chin, W. W. (1998). The Partial Least Squares Approach to Structural Equation Modeling. In G. A. Marcoulides (Ed.), Modern methods for business research, 295-336. Mahwah, NJ: Lawrence Erlbaum Associates Publisher.

[150] Chin,W. W., Marcolin B. L., \& Newsted P. R. (2003). A Partial Least Squares Latent Variable Modeling Approach for Measuring Interaction Effects: Results from a Monte Carlo Simulation Study and an Electronic-Mail Emotion / Adoption Study, Information Systems Research, 14, 2, 189-217.

[151] Fornell, C., \& Larcker, D. F. (1981). Evaluating Structural Equation Models with Unobservable Variables and Measurement Error. Journal of Marketing Research, 18, 39-50.

[152] Hair, J. F., Anderson, R. E., Tatham, R. L., \& Black, W. C. (1998). Multivariate Data Analysis, $5^{\text {th }}$ ed. London: Prentice-Hall.

[153] Fornell, C., \& Larcker, D. F. (1981). Evaluating Structural Equation Models with Unobservable Variables and Measurement Error. Journal of Marketing Research, 18, 39-50.

[154] Tenenhaus, M., Vinzi, V., Chatelin, Y., \& Lauro, C. (2005). PLS Path Modeling. Computational Statistics \& Data Analysis, 48, 159-205.

[155] Ringle, C. M., Wende, S., \& Will, S. (2005). SmartPLS 2.0 (M3) Beta. Hamburg. Retrieved fromhttp://www.smartpls.de

[156] Chin, W. W. (1998). The Partial Least Squares Approach to Structural Equation Modeling. In G. A. Marcoulides (Ed.), Modern methods for business research, 295-336. Mahwah, NJ: Lawrence Erlbaum Associates Publisher.

\section{AUTHOR'S BIOGRAPHY}

Esin Akay, PhD Candidate in the Department of Business Administration at Yeditepe University, Istanbul Turkey. She has written a Master's Thesis about learning organizations. Recently, she has been writing her PhD Dissertation on the topic of corporate governance. Her main research interests are human resources management, learning organizations, transformational leadership, human capital, social capital and innovation.

Ozlem Kunday, Associate Professor and Vice Chair in the Department of Business Administration at Yeditepe University, Istanbul Turkey. She is member of GEM Project Team in Turkey and member of Management Application and Research Center.Her primary research interests areentrepreneurship, start-ups, SME management and human resources management. She has authored, co-authored, translated and edited books on entrepreneurship, contemporary management, healthcare management and human resource management.

Citation: Esin Akay,Ozlem Kunday. “ An Empirical Study of HRM Systems, Human and Social Capital Development and their Influence on Innovation Capabilities" International Journal of Managerial Studies and Research (IJMSR), vol 6, no. 5, 2018, pp. 21-39. doi:http://dx.doi.org/10.20431/2349-0349.0605003.

Copyright: (C) 2018 Authors. This is an open-access article distributed under the terms of the Creative Commons Attribution License, which permits unrestricted use, distribution, and reproduction in any medium, provided the original author and source are credited. 